INDEPENDENT JOURNAL OF MANAGEMENT \& PRODUCTION (IJM\&P)

http://Www.ijmp.jor.br

V. 10, n. 6, November-December 2019

ISSN: 2236-269X

DOI: 10.14807/ijmp.v10i6.947

\title{
FINTECH IN PAKISTAN: A QUALITATIVE STUDY OF BANK'S STRATEGIC PLANNING FOR AN INVESTMENT IN FIN-TECH COMPANY AND ITS CHALLENGES
}

\author{
Sehrish Butt \\ University of Central Punjab, Pakistan \\ E-mail: Sehrish.butt786@gmail.com \\ Zeeshan Ahmad Khan \\ University of Central Punjab, Pakistan \\ E-mail: Zeeshan.khan687@gmail.com
}

Submission: $12 / 28 / 2018$

Revision: $2 / 8 / 2019$

Accept: 3/13/2019

\section{ABSTRACT}

The purpose of this study is to explore the strategic considerations in the process of searching for Fin-Tech investment targets and what challenges are faced by banks while its implementation. This study has examined the problems faced by banking sectors in investing in Fin-Tech. This study used a case study methodology of 5 banks in Pakistan on convenience based sampling. The major data sources include the field notes, recording and transcription of interviews collected from branch managers. The results relate to: (1) Fin-Tech in banking sector of Pakistan (2) Banks planning for the adoption of new financial technology, (3) Criteria for selecting Fin-Tech company, (4) Technology as banking career,(5) Barriers in the implementation of Fintech in Pakistan. It is suggested that Pakistan must upgrade its Fin-Tech infrastructure besides doing other things. The government is also needed to concentrate more efforts to overcome these problems.

Keywords: Fin-Tech, Banking Sector, Barriers, Pakistan 
INDEPENDENT JOURNAL OF MANAGEMENT \& PRODUCTION (IJM\&P)

http://www.ijmp.jor.br

v. 10, n. 6, November - December 2019

ISSN: 2236-269X

DOI: 10.14807/ijmp.v10i6.947

\section{INTRODUCTION}

Traditional banks are playing key role in the financial industry and the rapid technological development in financial sector has evolved the world economic to shift to the digital channels gradually. Over the last decade, the financial industry is rapidly been transformed by the financial technology (Fin-Tech) companies (SKAN; DICKERSON; MASOOD, 2015). Fin-Tech is also categorized as a new type financial industry that combines information technology and financial services like payments, remittances and asset management (LEE; KIM, 2015).

The Fin-Tech has generated various business models and customer requirements. It has a great impact on various aspects of the economics i.e. payment services, financial markets and banking sector (SALMONY, 2014). Many innovated electronic services have been introduced in market to fill the financial market gap. This new technology is easy to use, fast transaction speed and a wide choice of service providers. After the introduction of PayPal, digital currency etc the financial sector has become digitalized (GONZÁLEZ, 2004).

According to recent survey, global Fin-Tech investment growth is accelerated in Asia and Europe in 2016. The global investment increased to $\$ 5.3$ billion in first quarter of 2016 and approximately $62 \%$ investment is going to Fin-Tech companies in Europe \& Asia-Pacific. However, collaborative and disruptive Fin-Tech companies have different investment patterns. Some of the challenges while adopting Fin-Tech company i.e. I.T security issues, adoption of business model, regulation matters, managerial, cultural, operational, I.T skills \& compatibility differences and many other aspects (SHUTTLEWOOD; VOLIN; WOZNIAK, 2016).

\subsection{Fin-Tech in Pakistan}

In Pakistan, banking sector is first adopter of Fin-Tech and increasing its financial services rapidly. Effective utilization of Fin-Tech helps to save time, promote new products \& services and compete in international markets. Fin-Tech comprises of internet banking, mobile banking, ATM and many other banking facilities relevant to technology (KAZMI, 2003).

Traditional Fin-Tech works together with financial service providers in capacity of their technology providers by traditional pricing models. Whereas, Emergent FinTech refers to the new category of Fin-Tech that partner with financial service provider 
INDEPENDENT JOURNAL OF MANAGEMENT \& PRODUCTION (IJM\&P)

http://Www.ijmp.jor.br

v. 10, n. 6, November-December 2019

ISSN: 2236-269X

DOI: 10.14807/ijmp.v10i6.947

through new engagement modes. The Table 1 below shows the traditional and emergent Fin-Tech providers in Pakistan

Table 1: Traditional \& Emergent Fin-Tech Providers

\begin{tabular}{|l|l|l|l|l|l|}
\hline Traditional Fin-Tech & Location & Vertical & Emergent Fin-Tech & Location & Vertical \\
\hline MONET & Karachi & Payments & ONELOAD & Lahore & Payments \\
\hline INNOV8 & Lahore & $\begin{array}{l}\text { Branchless } \\
\text { banking, MFI }\end{array}$ & RED BUFFER & Islamabad & $\begin{array}{l}\text { Big } \\
\text { Analytics }\end{array}$ \\
\hline TPS & Karachi & Payment & BATWA & Karachi & Payments \\
\hline AUTOSOFT & Lahore & Paymnets, MFI & PAYLOAD & Karachi & Payments \\
\hline ABACS & Lahore & MFI & FINJA & Karachi & Payments \\
\hline
\end{tabular}

In Pakistan, industries are not aware of Fin-Tech and according to report, 72\% of organizations are not aware of Fin-Tech. In Pakistan, there are number of challenges and barriers in development of Fin-Tech. Very few Fin-Tech companies are operating in Pakistan and a major portion of Fin-Tech investment is in banking sector (KANWAL, 2017).

The introduction of e-banking has revolutionized the banking sector and contribution of technology is now considered as the main reason for success of banking sector. There are many products of Fin-Tech that includes internet banking, telephone banking, mobile banking and many more. Internet banking is the main route to enhance the financial transactions and maintain long run relations with clients.

Due to advance services of Fin-Tech, a strong relation is created between clients and banks i.e. it has provided multiple reliable and convenient ways of communication between banks and clients. Now, it is the responsibility of head office to train their branch employees about innovative Fin-Tech products (AKHLAQ , 2011).

\subsection{Problem Statement:}

The fusion of technology and banking sector has played a very vital role in development of banking sector. Globally, Fin-Tech investment is accelerating very drastically. However, involvement of Fin-Tech in banking sector is very much limited. The purpose of this study is to identify the importance of Fin-Tech and to figure out the challenges and barriers in the adoption of Fin-Tech in Pakistan.

\section{LITERATURE REVIEW}

The impact of information technology on the banking industry can be seen globally (OTUBU; ANAYASI, 2009). The findings of Mehmood, Nisar and Rehman, (2015) showed that information technology has a positive and significant impact on 
INDEPENDENT JOURNAL OF MANAGEMENT \& PRODUCTION (IJM\&P)

http://Www.ijmp.jor.br

v. 10, n. 6, November - December 2019

ISSN: 2236-269X

DOI: 10.14807/ijmp.v10i6.947

banking sector performance. Tayoung (2008) explained the imporatnce of adoption of financial technologies by the banking sector as it determine the success of Fin-Tech in banking industry.

According to Chiranjeevi and Umamheswari (2014), the banking sector is increasing its innoative IT products and paper work is becoming less in traditional banking and is being replaced by Fin-Tech. The findings of Sartape (2016) showed the major barriers and issues in implementation of Fin-Tech in Banks include flexibility, information management, re-engineering and transformation.

Surulivel, Vijayabanu, Amudha and Charumathi (2013) stated that commercial banks can reduce cost by implementing various information technology innovations. In India, the implementation of information technology has minimized cost by $28 \%$. Mahmood (2013) argued that use of IT products by banks have significant positive impact on service quality.

Further, service quality has a significant positive impact on customer satisfaction in Pakistan. Puschmann, (2017) conducted a research to examine the importance of Fin-Tech and challenges, roles and trend of Fin-Tech in financial sector. The findings showed that Fin-Tech improve the economy of country better than tradition system.

Recently most of the innovation in Fin-Tech is because of implementation of new payment methods and introduction of cryptocurrency. It had led to the establishment of innovative technology like block chain technology that is considered as the backbone of virtual currency (MAINELLI; SMITH , 2015).

Fin-Tech has completely changed the face of global financial sector by offering number of financial products that have solved many problems of customers. The typical example of Fin-Tech is PayPal, the leading company which is transforming the nature of transactions and money management by online trading and online payment system (DESAI, 2015).

Conner (2013) stated that one of th major changes of Fin-Tech in global economy is in field of lending. Traditionally, only banking institutions were authorized for lending transactions and customers would have to fulfill all the requirements laid down by banks including business contracts, mortgage papers, guarantee to pay back loan and many other documents (KUZNETSOV, 2016). 
Fin-Tech has a great impact on financial market and consumer finance. IT companies are developing various easy to use internet technologies. Many nonfinancial companies like ICT companies are entering into financial market and this can be threat to financial services. Therefore, financial companies are paying attention to Fin-Tech industry and analyzing its impact on their own business (SON; LEE; HEEWOONG, 2013).

\section{METHODOLOGY}

In case of exploratory study, case study research can be used (BHUTTA et al., 2013). According to Barkley (2006), case study can be used when there is a need of holistic and in depth study about less known phenomenan. Case studies are best to use when exploring a new concept as it provides a great source of quantitative and qualitative data.

This study is a qualitative study that uses in-depth interview to collect the data. The purpose of this study is to identify the importance of Fin-Tech and challenges faced by banks while implementation of Fin-Tech in Pakistan. Commercial banks are selected for the study to know the Fin-Tech involvements in banks and their implementation in Pakistani banking sector.

The respondents of this study are from commercial banks. Interviews were conducted from branch managers of five commercial banks and saturation point was achieved as suggested by (DEPAULO, 2010). The measurement of this research consists of one set of open-ended question which formed by the researchers in exploring the understanding of Fin-Tech in banking sector of Pakistan. After transcription of interviews, Tag clouds were created by using website tagcrowd.com.

\section{FINDINGS \& DISCUSSION}

The interviews were carefully transcribed and tag clouds were made using online resources. The findings mentioned below are based on interviews, field notes and tag clouds.

\subsection{Fin-Tech in Banking Sector of Pakistan}

Every bank knows the importance of Fin-Tech. Financial technologies and the innovative companies providing Fin-Tech services to the banking sector are the key element for the successful banking sector. One of the respondent said that "Fin-Tech 
has made the banking sector more efficient, quality service and cost cutting edge for customers".

It is a big tool for the customer satisfaction and to compete in the market. In Pakistan, people are less familiar about the importance of Fin-Tech, most of the banks are currently far behind with the competition. there are number of reasons, inflation are the major reason in Pakistan.

\title{
4.2. Banks Planning for The Adoption of New Financial Technology
}

Few banks are taking initial step towards the adoption of the new technology, most of the banks only adopt new technology or change when they feel pressure from other banks. As one of the respondents said,

\begin{abstract}
"When other banks adopt technology than most of the banks fell the need of the adoption of the technology for their banks, but firstly they look for the cost cutting benefits for their banks".
\end{abstract}

Customer satisfaction is important element but reluctant due to some economic uncertainty in markets.

\subsection{Criteria for Selecting Fin-Tech Company}

History and reputation of a Fin-Tech company is one of the big criteria almost in every bank. Then they look upon the need of the software, products, cost evaluation and other aspects matter. Criteria also set by the SBP about the Fin-Tech companies. Time demand is also one of the important elements. One of the respondents said,

\begin{abstract}
"Fin-Tech companies which are most suitable with their products are most suitable for the company. Almost every bank goes for the SWOT analysis before adopting any Fin-Tech company for their banks. Customer satisfaction, cost evaluation and risk mitigation are the key factor for the criteria".
\end{abstract}

\subsection{Technology as Banking Career}

Machines are now taking the place of human beings. Technology innovations are making everything more comfortable and time saving. One of the respondents said,

"Fin-Tech companies are most popular in banking sector. Every transaction in financial services and Fin-Tech companies are providing these services to banks not only in low cost but high-quality services for the banks".

Technology is making the world more comfortable and time saving. Although in Pakistan there are many economic uncertainties which can be a problem in the way 
INDEPENDENT JOURNAL OF MANAGEMENT \& PRODUCTION (IJM\&P)

http://Www.ijmp.jor.br

V. 10, n. 6, November-December 2019

ISSN: 2236-269X

DOI: 10.14807/ijmp.v10i6.947

of innovation and adoption but with the passage of time Fin-Tech trend is increasing but with the decreasing rate.

\title{
4.5. Barriers in The Implementation of Fintech In Pakistan
}

There are number of barriers and challenges in the implementation of financial technologies, in banking sector of Pakistan. The most important barrier is the literacy rate of Pakistan. People are not enough literate to operate new technologies easily. Most of the respondents said, "People are reluctant to accept change in Pakistan". One of the respondents highlighted the issues,

\begin{abstract}
"There are many issues, age factor matters a lot, inflation rate in Pakistan, economic conditions in Pakistan, less trust on online services, hackers and security issues, less access to banks, most of the people live in rural areas where no banks facilities".
\end{abstract}

Few people are familiar about the Fin-Tech. In Pakistan poverty rate is one of the barrier, people are cost conscious as compare to time. People are more feasible on the traditional banking work. Still Pakistan is far away from the IT development race of this world.

\section{CONCLUSION AND RECOMMENDATION}

The purpose of this study was to identify the importance and barriers in implementation of Fin-Tech in Pakistani banks. Based on our findings, it can be concluded that Fin-Tech is in early stages in banking sector of Pakistan. Banks in Pakistan prefer to outsource the financial activities to Fin-Tech organizations due to many reasons i.e. efficient quality, innovative technologies, software maintenance, competitive edge in market etc.

Along with these Fin-Tech benefits, there are many problems in implementing Fin-Tech in Pakistan. One of the major reasons is customer acceptability i.e. customers are reluctant to adopt financial innovations in Pakistan. The reason of less customer acceptability is less literacy rate and high poverty rate and that is why they are unaware of latest Fin-Tech products.

Security threat is also a major issue i.e. people prefer to visit branches for their banking transactions rather than using financial technology just to ensure the privacy and security of their transactions.

There should be positive and encouraging steps from state banks and other regularity authorities for development of Fin-Tech in Pakistan. Fin-Tech is not only 
efficient and productive for banking sector but we can also utilize it effectively in other financial and non-financial organizations. In today's competitive world, no organization can sustain in market if it is not up-to-date with latest technologies and innovations.

Regularity authorities should educate people about technological innovations in financial field so that they can perform financial activities more efficiently in international markets. We would like to recommend that seminars and training workshops regarding Fin-Tech should be conducted frequently to promote Fin-Tech in Pakistan.

In addition, there is need to establish Fin-Tech consortium in Pakistan. There is a need to promote digital payments in Pakistan and branchless banking will be great step towards digitalization of banking sector.

\section{REFERENCES}

AKHLAQ , M. A. (2011) Internet Banking in Pakistan: Finding Complexities . Journal of Internet Banking and Commerce .

CHIRANJEEVI, A.; UMAMHESWARI, B. (2014) Implementation of Information Technology in Banking Sector. Tactful Management Research Journal, v. 3, n. 1, p. 1-5.

CONNER, C. (2013) Would You Borrow From PayPal? PayPal's New Small Business Loans. Retrieved from Forbes: https://www.forbes.com/sites/cherylsnappconner/2013/09/25/paypal-introducessmall-business-loans/\#5c50c28e1fe5

DESAI, F. (2015) The evolution of fintech. Retrieved from Forbes: http://www.forbes.com/sites/falgunidesai/2015/12/13/the-evolution-offintech/\#349c7f184ccb

GONZÁLEZ, A. G. (2004) PayPal: the legal status of c2c payment systems. Computer law \& security review, p. 293-299.

HUNGI, J.-L.; LUO, B. (2016) FinTech in Taiwan: a case study of a Bank's strategic planning for an investment in a FinTech company . financial Innovation, p. 1-16.

HUSSAIN, I. (2011) Financial Sector Regulation in Pakistan: The way Forward. SBP Research Bulletin.

KANWAL, M. (2017) Fin-Tech in Pakistan: challanges, Opportunities and Recommendations. Lahore: TECHJUICE.

KAZMI, S. H. (2003) IT in Core Industries. Pakistan \& Gulf Economist, p. 12-14.

KUZNETSOV, N. (2016) How Fintech Is Changing The Way We Handle Money. Retrieved from Huffpost: http://www.huffingtonpost.com/nikolai-kuznetsov/howfintech-is-changing-t_b_11240444.html

LEE, T.-H.; KIM, H.-W. (2015) An Exploratory Study on Fintech Industry in Korea: Crowdfunding Case. 2nd International conference on Innovative Engineering 
INDEPENDENT JOURNAL OF MANAGEMENT \& PRODUCTION (IJM\&P)

http://Www.ijmp.jor.br

V. 10, n. 6, November-December 2019

ISSN: 2236-269X

DOI: 10.14807/ijmp.v10i6.947

Technologies. Bangkok.

MAHMOOD, F. (2013) Impact of Information TEchnology USage by Banks on Customer Satisfaction in Banking Sector of Pakistan. Management and Administrative Sciences Review, p. 221-232.

MEHMOOD, B.; NISAR, A.; REHMAN, H. (2015) Technology MAtters: Evidence from Pakistani Banking Sector using Flexible Transcendental Logarithmic Production Function. Pakistan Economic and Social Review, v. 53, n. 2, p. 203- 224.

MAINELLI, M.; SMITH, M. (2015) Sharing ledgers for sharing economies: an exploration of mutual distributed ledgers. The Journal of Financial Perspectives: FinTech, p. 1-47.

OTUBU, F.; ANAYASI, A. (2009) Mobile Phone Technology in Baniking system: Its economic effect. Research Journal of Information Technology, p. 1-5.

PAKISTAN, S. B. (2015) Quarterly Branchless Banking Newsletter. State Bank of Pakistan .

PUSCHMANN, T. (2017) Fin-Tech. Bus Inf Syst Eng, p. 69-76.

PWC, P. I. (2016) How Fin-Tech is shaping Financial Services, Global FinTech Report. PricewaterhouseCoopers International Limited.

RAZZAQ, L.; PARACHA, M. (2017) The Fin-Tech Ecosystem of Pakistan. Pakistan.

REGI, S. B.; FRANCO, C. (2017) Information Technology in Indian Banking SectorChallanges and Opportunities. International Journal of Multidisciplinary Research and Modern Education, p. 78-83.

SALMONY, M. (2014) Access to accounts: Why banks should embrace an open future. Journal of payments strategy \& systems.

SARTAPE, A. K. (2016) Information Technology and Banks; Trend Issues and Challanges. Intrnational REsearch Journal of Multidisiplinary Studies, v. 2, p. 12, p. 1-9.

SBP, S. B. (2015) Branchless Banking Newsletter. Karachi: State Bank of Pakistan.

SHUTTLEWOOD, P.; VOLIN, M.; WOZNIAK, L. (2016) Global Fintech Investment Growth Continues in 2016 Driven by Europe and Asia. Accenture.

SKAN, J.; DICKERSON, J.; MASOOD, S. (2015) The future of fintech and banking: digitally disrupted or reimagined? Retrieved from Accenture Consulting: https://www.accenture.com/us-en/insight-future-fintech-banking

SON, J. E.; LEE, S.; HEE-WOONG, K. (2013) A Systems Thinking Approach to the Enhancement of Social Capital: In Case of Social Media Users. Information Systems Review, p. 21-40.

SURULIVEL, S. T.; VIJAYABANU, C.; AMUDHA, R.; CHARUMATHI, B. (2013) Impat of Information Technology Investment on the Cost Efficiency of Indian Private sector Banks- A Stochastic Frontier Approach. Research Journal of Applied Sciences, Engineering and Technology, p. 85-92.

TAYOUNG, T. A. (2008) Adoption of Innovative Financial Technologies by Commercial baks: the case of Nordea Bank. Journal of Turun Yliopisto University of Turku. 
INDEPENDENT JOURNAL OF MANAGEMENT \& PRODUCTION (IJM\&P)

http://Www.ijmp.jor.br

v. 10, n. 6, November - December 2019

ISSN: 2236-269X

DOI: 10.14807/ijmp.v10i6.947

VASUDEVAN, A. (2003) Some perspectives on IT up gradation in the financial sectors. Journal of Indian Institute of Bankers., p. 36-38. 